\title{
Site-specific height-diameter and stem volume equations for Lebombo-ironwood
}

\author{
T.M. Magalhães
}

\section{Introduction}

Lebombo-ironwood (Androstachys johnsonii Prain) is an evergreen tree species from Picrodendraceae family, and can grow up to $20 \mathrm{~m}$ in height (Molotja et al. 2011). In Mozambique, this tree species rarely exceeds $35 \mathrm{~cm}$ in diameter at breast height (DBH) (Magalhães \&
Magalhães T.M., 2017. Site-specific height-diameter and stem volume equations for Lebombo-ironwood. Ann. For. Res. 60(2): 297-312.

Abstract. Height-diameter (H-D) and stem volume equations are indispensable tools for forest management and have a wide use in forestry, however they are lacking for Lebombo-ironwood. Based on a dataset of 1144 Lebombo-ironwood trees destructively measured for height and stem volume, $\mathrm{H}-\mathrm{D}$ and stem volume models were fitted using mixed-effects and dummy variables models. Random-effects and dummy variables were the different growing sites, as they affect $\mathrm{H}-\mathrm{D}$ relationships and therefore stem volume models. Different model forms were compared to each other with regard to the sources of errors. The error due to uncertainty in the model parameter estimates was insignificant for mixed-effects models, whilst the error due to model misspecification was relatively larger for dummy variables $\mathrm{H}-\mathrm{D}$ functions when compared to the mixed-effects ones. However, both mixed-effects and dummy variables models were similar in terms of error due to residual variability around model prediction. Overall, mixed-effects and dummy variables models did not differ in terms of predictive ability and accuracy.

Keywords fixed-effects, random-effects, dummy variables, Androstachys johnsonii Prain.

Authors. Tarquinio Mateus Magalhães (tarqmag@yahoo.com.br) - Departamento de Engenharia Florestal, Universidade Eduardo Mondlane, Campus Universitário, Edifício no. 1, 257 Maputo, Moçambique.

Manuscript received April 24, 2017; revised August 3, 2017; accepted August 10, 2017; online first August 31, 2017. 
first class timber and it is lawful harvested at $30 \mathrm{~cm} \mathrm{DBH}$ (Decree 12/2002). It is primarily used for flooring, but it is also suitable for marine uses, turnery, furniture and interiors (Bunster 2006). Lebombo-ironwood has an important socioeconomic value to local communities, which sell and use its stakes and poles in the construction of homes, shelters, and furniture. It is the main source of income in the Funhalouro and Mabote districts (MAE 2005a, b). Nonetheless, this species is not managed, mainly due to lack of management tools, e.g. height-diameter (H-D) and volume equations.

$\mathrm{H}-\mathrm{D}$ and stem volume equations have a wide use in forestry. $\mathrm{H}-\mathrm{D}$ relationships vary with growing environment (e.g. soil and weather conditions) and management (Sharma \& Zhang 2004). The variation in the H-D relationship makes the stem volume equations to vary in the same conditions as well, and restricts their use to the area from which the basic data were obtained (Loetsch et al. 1973, de Gier 1992). This indicates that growing sites or site effects need to be included in such models.

There are two kinds of subject-specific modelling methods (Wang et al. 2008, Fu et al. 2012) that can be applied to incorporate site-specific effects and account for the interregional variability: mixed-effects and dummy variables modelling methods.

Mixed-effects models estimate both fixed parameters (common to every subject) and random parameters (specific to each subject) simultaneously for the same model. The introduction of random-effects parameters into the model enables modelling the variability detected for given phenomena among different subjects, after defining a common fixed functional structure (Calama \& Montero 2004, Castedo-Dorado et al. 2006, Schimidt et al. 2011).

Mixed-effects models give an unbiased and efficient estimation of the fixed parameters of the model; improve the predictive ability if it is possible to predict the value of the random parameters for an unsampled location (Cala298 ma \& Montero 2004, Mehtätalo et al. 2015). Thus, mixed-effects models can be calibrated for new, previously not sampled sites quickly and effectively (Saunders \& Wagner 2008, Mehtätalo et al. 2015).

In regression analysis, dummy variables are independent variables which take the value of either zero or one (Garavaglia \& Sharma 2000, $\mathrm{Fu}$ et al. 2012) to indicate the absence or the presence of some categorical effect ( $\mathrm{Fu}$ et al. 2012). Dummy variables are a numeric standin for qualitative facts and have been commonly used to deal with categorical variables which are involved in quantitative methods ( $\mathrm{Li}$ et al. 2006, Tang et al. 2008). In a regression model, a dummy variable with a value of zero will cause its coefficient to disappear from the equation (Garavaglia \& Sharma 2000). Conversely, the value of one causes the coefficient to function as a supplemental intercept, because of the identity property of multiplication by one (Garavaglia \& Sharma 2000).

Mixed-effects models treat the subjects (e.g. growing sites) as random effects (Wang et al. 2008). In contrast, dummy variables models treat the subjects as fixed-effects, but different across individual subjects (Wang et al. 2008) thus they are named fixed individual effects (Baltagi 2005, Wang et al. 2007).

There is an intense debate of which of two subject-specific modelling methods should be used (Gelman 2005, Wang et al. 2008, Fu et al. 2012, Zeng 2014). Different studies have shown contradictory conclusions (Wang et al. 2008, Fu et al. 2012, Zeng 2014).

The objectives of this research were to (i) develop site-specific H-D and stem volume equations for Lebombo-ironwood; (ii) compare mixed-effects and dummy variables $\mathrm{H}-\mathrm{D}$ and stem volume models with regard to following sources of errors in model prediction: (1) error due to model misspecification, (2) error due to uncertainty in the model parameter estimates, and (3) error due to residual variability around model prediction. 


\section{Material and methods}

\section{Study area}

The research was conducted in Mozambique (18 $15^{\prime} \mathrm{S}, 35^{\circ} 00^{\prime} \mathrm{E}$, Fig. 1A), in Mecrusse woodlands of Mandlakazi, Chibuto, Mabote, Funhalouro, Mabalane and Chicualacuala districts (Fig. 1B). The physical and natural conditions for each district of the study area are summarized in Table 1. The districts were grouped according to similarity in physical and natural conditions, which are expected to influence largely the site quality and thus $\mathrm{H}-\mathrm{D}$ relationship and the stem volume equations. Therefore, three growing sites were defined as shown in Table 1.

\section{Data collection}

The data consisted of 1144 trees, with DBHs ranging from 5 to $50 \mathrm{~cm}$, destructively harvested in 2007 (276 trees), 2009 (397 trees), 2010 (341 trees), 2012 (93 trees) and 2014 (37 trees). Total height was measured with the tree felled as the length from ground to the tip of the tree. Stem was defined as the length of the

trunk from ground to a predefined top diameter. However, as data from different years were collected for different researches, the definition of top diameter varied slightly from year to year. For the 2007, 2009 and 2010 trees, the top diameter was $2.0 \mathrm{~cm}$; and for the 2012 and 2014 trees, the top diameter was $2.5 \mathrm{~cm}$.

The stump height also varied from year to year; however, its volume was calculated and included in the computation of stem volume. The stump volume was included in the stem volume to standardize the definition of the stem (from ground level to the height corresponding to 2.0 or $2.5 \mathrm{~cm}$ ) and avoid discrepancies in stem volume due to different stump lengths. Moreover, when estimating stem volume from volume equations, the tree height is measured using hypsometers, thus estimated as the vertical distance from ground level to the top of the tree, not excluding the stump.

The majority of the data from 2007 were obtained in the course of forest exploitation, thus the stump heights varied from tree to tree (from 12 to $31 \mathrm{~cm}$ ). However, to ensure adequate representation of the population, small and unusual large trees were felled and added to the sample; these trees had a predefined stump height of $15 \mathrm{~cm}$, as for trees from 2009 and 2010. Trees from
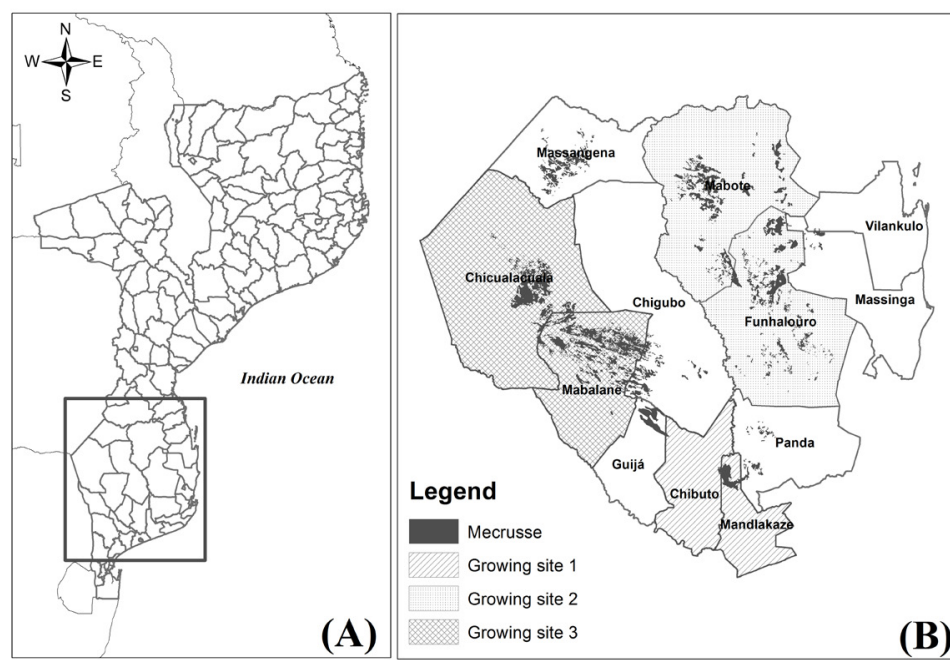

Figure 1 Study area showing the different districts and growing sites investigated
2012 and 2014 had a stump height of $20 \mathrm{~cm}$. Trees from 2012 were measured within sample plots laid out in the forest. Trees from 2009, 2010, and 2014 were measured randomly from the forest.

Prior to felling, the height of the stump was marked around the perimeter of the trunk using a marker. The chainsaw operator felled the trees following the marked perimeter. How- 
ever, in some trees, especially those with irregular shape of the outline of the cross-section, cutting exactly at marked perimeter was difficult. This must have induced errors in the volume estimate. Nonetheless, this error is expected to be negligible as $A$. johnsonii trees have approximately a circular cross-section and because whenever it was observed that the chainsaw operator missed the marked perimeter the stump height was re-measured.

The portion of the stem from stump height to the top diameter (major segment) was divided into 10 minor segments equal in length and the diameter of each minor segment was measured at the midpoint. The volume of the major segment was determined using Hohenadl's formula (Magalhães \& Seifert 2015a), and that of the stem was computed by summing the volume of the major segment and that of the stump, computed using either Huber's or Smalian's formula, depending on the number of diameter measurements taken.

The data were randomly split into training $(90.6 \%)$ and testing data $(9.4 \%)$, for model fitting and validation, respectively.

\section{Data analysis}

It is clear from Table 1 that the growing sites are different and that they are reflected in $\mathrm{DBH}$, height, and volume values (Table 2). Thus, it is expected the H-D relationships and stem volume models to vary from site to site (Sharma \& Zhang 2004, Adame et al. 2008). This justifies the use of site-specific models (Mugasha et al. 2016), as the H-D relationships are largely influenced by site index (Adame et al. 2008) and habitat (Huang et al. 2000). Thus, the regression parameters of $\mathrm{H}-\mathrm{D}$ and stem volume equations are expected to vary from one growing site to another, as trees from the same growing site tend to be more similar to each other than to trees from different growing sites.

In this study, to account for the interregional variability, the models were fitted using both mixed-effects and dummy variables regres300 sions. In mixed-effects regression, besides the fixed-effects parameters (common to every site), random-effects parameters (specific to each site) were added to the model (i.e. different sites were added as random-effects). In dummy variables regression, the site-effects were added to the model as dummy variables. Site-specific effects as described here were preferred over district-specific effects because districts are administrative divisions and, as such, are not expected to affect the model parameters. That is, administrative divisions may be composed by distinguished growing environments and different administrative divisions may be part of the same growing environment or ecological region. The latter case is what is observed in the study area. Therefore, districts with similar growing environment were grouped together. On the other hand, plot-level random effects were not considered because, as mentioned previously, not all trees were harvested within sampling plots, then the majority of the trees would lack random-effects.

The tested H-D model forms were asymptotic models (Table 3), as they are more consistent with biological growth curves characteristics (Adame et al. 2008), therefore biologically reasonable. Biologically reasonable models quite often produce more accurate predictions beyond the range of data used in model fitting (Fekedulengn et al. 1999).

\section{Mixed-effects modelling approach}

The H-D model forms in Table 3 were fitted in their linearized form to allow the use of linear least squares. Linear least squares were preferred over nonlinear ones because, unlike random-effects parameters, dummy variables cannot be added to nonlinear models (Cunia 1986a, Garavaglia \& Sharma 2000). For example, the Näslund (1937) mixed-effects H-D model form given in Eq.1 was linearized as given in Eq. 2. Similar linearization was applied for other H-D model forms (Table 3). This type of linearization has been widely used 
Table 1 Physical and natural conditions of the study area

\begin{tabular}{|c|c|c|c|}
\hline $\begin{array}{l}\text { Gro- } \\
\text { wing } \\
\text { site } \\
\end{array}$ & District & Climate, hydrology and tree characteristics & $\begin{array}{l}\text { Relieve, } \\
\text { topography and } \\
\text { altitude }\end{array}$ \\
\hline \multirow[t]{2}{*}{1} & Mandlakazi & $\begin{array}{l}\text { Climate: dry and humid tropical; Mean annual } \\
\text { precipitation: } 400 \text { to } 1000 \mathrm{~mm} \text {; Hydrology: } 63 \text { lakes } \\
\text { and } 2 \text { rivers. Characterised by relatively larger and } \\
\text { taller adult } A \text {. johnsonii trees. }\end{array}$ & $\begin{array}{l}\text { Relief and } \\
\text { topography: flat. } \\
\text { Altitude: } 50 \text { to } \\
200 \mathrm{~m} \text { a.s.l. }\end{array}$ \\
\hline & Chibuto & $\begin{array}{l}\text { Climate: dry tropical; Mean annual precipitation: } 400 \\
\text { to } 600 \mathrm{~mm} \text {; Hydrology: } 4 \text { rivers. Characterised by } \\
\text { relatively larger and taller adult } A \text {. johnsonii trees. }\end{array}$ & $\begin{array}{l}\text { Relief and } \\
\text { topography: flat. } \\
\text { Altitude: } 50 \text { to } \\
200 \mathrm{~m} \text { a.s.l. }\end{array}$ \\
\hline \multirow[t]{2}{*}{2} & Funhalouro & $\begin{array}{l}\text { Climate: dry tropical; Mean annual precipitation: } \\
500 \text { to } 800 \mathrm{~mm} \text {; Hydrology: not crossed by any river, } \\
\text { occurrence of meteorological droughts. Characterised } \\
\text { by medium to large (in DBH and height) adult } A \text {. } \\
\text { johnsonii trees. }\end{array}$ & $\begin{array}{l}\text { Relief and } \\
\text { topography: flat. } \\
\text { Altitude: } 100 \text { to } \\
200 \text { m a.s.l. }\end{array}$ \\
\hline & Mabote & $\begin{array}{l}\text { Climate: dry tropical; Mean annual precipitation: } 600 \\
\text { mm; Hydrology: not crossed by any river, occurrence } \\
\text { of meteorological droughts. Characterised by medium } \\
\text { to large (in DBH and height) adult } A \text {. johnsonii trees. }\end{array}$ & $\begin{array}{l}\text { Relief and } \\
\text { topography: flat. } \\
\text { Altitude: } 100 \text { to } \\
200 \mathrm{~m} \text { a.s.l. }\end{array}$ \\
\hline \multirow[t]{2}{*}{3} & Chicualacuala & $\begin{array}{l}\text { Climate: semi-arid and dry tropical; Mean annual } \\
\text { precipitation: } 500 \text { to } 800 \mathrm{~mm} \text {; Hydrology: } 5 \text { rivers, } \\
\text { occurrence of agricultural droughts. Characterised by } \\
\text { relatively thinner and shorter adult } A \text {. johnsonii trees. }\end{array}$ & $\begin{array}{l}\text { Relief and } \\
\text { topography: flat. } \\
\text { Altitude: }>200 \mathrm{~m} \\
\text { a.s.l. }\end{array}$ \\
\hline & Mabalane & $\begin{array}{l}\text { Climate: semi-arid and dry tropical; Mean annual } \\
\text { precipitation: } 500 \text { to } 800 \mathrm{~mm} \text {; Hydrology: } 7 \text { rives, } \\
\text { occurrence of agricultural droughts. Characterised by } \\
\text { relatively thinner and shorter adult } A \text {. johnsonii trees. }\end{array}$ & $\begin{array}{l}\text { Relief and } \\
\text { topography: flat. } \\
\text { Altitude: }>200 \mathrm{~m} \\
\text { a.s.1. }\end{array}$ \\
\hline
\end{tabular}

Note. Source: DINAGECA (1997), FAO (2003), MAE (2005a-f), Magalhães \& Seifert (2005d).

(Siipilehto 2000, Husch et al. 2003, van Laar \& Akça 2007, Schmidt et al. 2010, Kershaw Jr. et al. 2017).

$$
\begin{aligned}
& H=1.3+\frac{D^{2}}{\left[\left(\alpha+\theta_{\alpha \mathrm{j}}\right)+\left(\beta+\theta_{\beta \mathrm{j}}\right) D\right]^{2}}+\varepsilon \\
& \frac{\mathrm{D}}{\sqrt{\mathrm{H}-1.3}}=\left(\alpha+\theta_{\alpha \mathrm{j}}\right)+\left(\beta+\theta_{\beta \mathrm{j}}\right) \mathrm{D}
\end{aligned}
$$

Similarly, the Schumacher \& Hall (1933) mixed-effects volume model is as follows:

$$
\mathrm{V}=\left(\alpha+\theta_{\alpha \mathrm{j}}\right) \mathrm{D}^{\left(\beta+\theta_{\beta \mathrm{j}}\right)} \mathrm{H}^{\left(\gamma+\theta_{\gamma j}\right)} \varepsilon
$$

where: $\mathrm{H}$ - tree height; D - diameter at breast height (DBH); V - stem volume; $\alpha, \beta$ and $\Upsilon$
- fixed-effects regression parameters; $\Theta_{\mathrm{ij}}$ - random parameter $i$ for site $j, j=1,2,3$, e.g. $\Theta_{\alpha 1}$ $=$ random parameter $\alpha$ for site 1. For Eq. 2, $\Theta_{\alpha \mathrm{j}}$ and $\Theta_{\beta \mathrm{j}}$ are the random intercept and random slope for growing site $j$.

Eq. 3 was linearized by $\log$ transformation, addressing, therefore, the heteroskedasticity as, quite often, the error variance is functionally related to the independent variables in regression (Parresol 1999). Thus, Eq. 3 became as given in Eq. 4.

$$
\ln \mathrm{V}=\mathbf{a}+\left(\beta+\theta_{\beta \mathrm{j}}\right) \ln \mathrm{D}+\left(\gamma+\theta_{\gamma \mathrm{j}}\right) \ln \mathrm{H}+\boldsymbol{\varepsilon}^{\prime}
$$

where: $\mathrm{a}=\ln \left(\alpha+\theta_{\alpha \mathrm{j}}\right), \varepsilon^{\prime}=\ln \varepsilon$. Thus, the pre- 
Table 2 Summary statistics of the training and testing samples

\begin{tabular}{|c|c|c|c|c|c|c|c|c|c|}
\hline \multirow{2}{*}{$\begin{array}{l}\text { Growing } \\
\text { site }\end{array}$} & & \multirow{2}{*}{$\frac{\text { Training data }}{\mathrm{DBH}[\mathrm{cm}]}$} & \multicolumn{7}{|c|}{ Testing data } \\
\hline & & & $\mathrm{H}[\mathrm{m}]$ & $\mathrm{V}\left[\mathrm{m}^{3}\right]$ & $\mathrm{ff}_{1.3}$ & $\mathrm{DBH}[\mathrm{cm}]$ & $\mathrm{H}[\mathrm{m}]$ & $\mathrm{V}\left[\mathrm{m}^{3}\right]$ & $\mathrm{ff}_{1.3}$ \\
\hline \multirow{6}{*}{1} & $\mathrm{n}$ & 271 & 271 & 271 & 271 & 33 & 33 & 33 & 33 \\
\hline & Mean & 16.74 & 11.33 & 0.1893 & 0.5255 & 18.70 & 11.20 & 0.1929 & 0.5211 \\
\hline & Min & 5.00 & 3.60 & 0.0038 & 0.3893 & 5.00 & 5.30 & 0.0062 & 0.3893 \\
\hline & Max & 50.00 & 22.50 & 1.8845 & 0.6967 & 35.00 & 17.70 & 0.7957 & 0.6967 \\
\hline & SD & 8.47 & 3.72 & 0.2152 & 0.0222 & 8.11 & 3.78 & 0.1910 & 0.0500 \\
\hline & $\mathrm{CV}[\%]$ & 50.61 & 32.84 & 113.65 & 4.22 & 43.35 & 31.00 & 85.68 & 9.60 \\
\hline \multirow{6}{*}{2} & $\mathrm{n}$ & 457 & 457 & 457 & 457 & 40 & 40 & 40 & 40 \\
\hline & Mean & 13.53 & 10.91 & 0.1248 & 0.5904 & 17.45 & 11.38 & 0.1810 & 0.5143 \\
\hline & Min & 5.00 & 1.80 & 0.0026 & 0.3869 & 6.00 & 7.92 & 0.0130 & 0.3914 \\
\hline & Max & 47.00 & 16.80 & 1.2969 & 0.7187 & 30.50 & 15.16 & 0.5417 & 0.6631 \\
\hline & $\mathrm{SD}$ & 6.71 & 2.46 & 0.1494 & 0.0413 & 7.11 & 1.70 & 0.1437 & 0.0656 \\
\hline & $\mathrm{CV}[\%]$ & 49.59 & 22.55 & 119.73 & 6.99 & 40.72 & 13.73 & 79.37 & 12.75 \\
\hline \multirow{6}{*}{3} & $\mathrm{n}$ & 309 & 309 & 309 & 309 & 34 & 34 & 34 & 34 \\
\hline & Mean & 12.07 & 8.84 & 0.1001 & 0.6047 & 14.88 & 7.36 & 0.1209 & 0.5650 \\
\hline & Min & 5.00 & 1.50 & 0.0015 & 0.5409 & 5.00 & 1.50 & 0.0029 & 0.5309 \\
\hline & Max & 33.00 & 14.80 & 0.3900 & 0.7658 & 29.00 & 11.88 & 0.3431 & 0.7001 \\
\hline & SD & 4.67 & 2.86 & 0.0639 & 0.0391 & 4.67 & 1.91 & 0.0395 & 0.0408 \\
\hline & $\mathrm{CV}[\%]$ & 38.70 & 38.70 & 101.31 & 6.47 & 37.76 & 30.41 & 81.23 & 7.23 \\
\hline \multirow{6}{*}{$\begin{array}{l}\text { Whole } \\
\text { popu- } \\
\text { lation }\end{array}$} & $\mathrm{n}$ & 1037 & 1037 & 1037 & 1037 & 107 & 107 & 107 & 107 \\
\hline & Mean & 13.93 & 10.40 & 0.1343 & 0.5777 & 17.02 & 10.73 & 0.1748 & 0.5325 \\
\hline & Min & 5.00 & 1.50 & 0.0015 & 0.3869 & 5.00 & 1.50 & 0.0029 & 0.3893 \\
\hline & Max & 50.00 & 22.50 & 1.8845 & 0.7658 & 35.00 & 17.70 & 0.7957 & 0.7658 \\
\hline & SD & 6.94 & 3.40 & 0.1591 & 0.0483 & 7.24 & 3.79 & 0.1562 & 0.0580 \\
\hline & CV [\%] & 49.80 & 27.41 & 129.12 & 8.36 & 44.65 & 36.53 & 102.84 & 10.89 \\
\hline
\end{tabular}

Table 3 Summary statistics of the training and testing samples

\begin{tabular}{llll}
\hline $\mathrm{H}-\mathrm{D}$ model form & Author (s) & Volume model form & Author(s) \\
\hline $\mathrm{H}=1.3+\mathrm{D}^{2} /(\alpha+\beta \mathrm{D})^{2}+\varepsilon$ & Näslund (1937) & $\mathrm{V}=\alpha \mathrm{D}^{\beta} \varepsilon$ & $\begin{array}{l}\text { Stoffels (1953) } \\
\text { Schumacher \& Hall }\end{array}$ \\
$\mathrm{H}=1.3+\mathrm{D}^{2} /\left(\alpha \mathrm{D}^{2}+\beta \mathrm{D}+\Upsilon\right)+\varepsilon$ & Strand (1959) & $\mathrm{V}=\alpha \mathrm{D}^{\beta} \mathrm{H}^{\gamma} \varepsilon$ & $(1933)$ \\
$\mathrm{H}=1.3+\alpha \mathrm{D} /(\beta+\mathrm{D})+\varepsilon$ & $\begin{array}{l}\text { Menten \& Michalis } \\
(1913)\end{array}$ & $\mathrm{V}=\alpha\left(\mathrm{D}^{2} \mathrm{H}\right)^{\beta} \varepsilon$ & Spurr (1952)
\end{tabular}

Note. Abbreviations: $\mathrm{H}$ - tree height, D - diameter at breast height (DBH), $\mathrm{V}$ - stem volume, $\alpha, \beta$ and $\Upsilon$ - fixed-effects regression parameters.

dicted volume $(\hat{\mathrm{V}})$ has to be obtained by back-transforming Eq. 4 into original values. However, as logarithmic transformation induces a systematic bias in the final dependent variable (Chave et al. 2005), the back-transformed equation must be corrected for that bias using the correction factor $\exp \left(\mathrm{S}_{\mathrm{r}}^{2} / 2\right)$ suggested by Baskerville (1972). This results in following estimated volume from the Schumacher \& Hall (1933) model form:

$$
\hat{\mathrm{V}}=\exp \left(\alpha+\theta_{\mathrm{aj}}+\mathrm{S}_{\mathrm{r}}^{2} / 2\right) D^{\left(\beta+\theta_{\mathrm{ij}}\right)} \mathbf{H}^{\left(\gamma+\theta_{i j}\right)}
$$


where $\mathrm{S}_{\mathrm{r}}^{2}$ is the variance of the logarithmic residuals. Analogously, log transformation, back-transformation and bias correction was applied to Stoffels (1953) mixed-effects volume model, resulting in Eq. 6.

$\hat{V}=\exp \left(\alpha+\theta_{\mathrm{aj}}+\mathrm{S}_{\mathrm{r}}^{2} / 2\right) \mathrm{D}^{\left(\beta+\theta_{\mathrm{gi}}\right)}$ fore, only the intercept was assumed to change between sites, as it was found to represent the variation between subjects (Zeng et al. 2011, Fu et al. 2012).

The linearized Näslund (1937) H-D dummy variables model is given in Eq. 9 and the height is predicted using the back-transformed function in Eq. 10.
Mixed-effects models were fitted using the lmer function of lme4 pack-

$\frac{\mathrm{D}}{\sqrt{\mathrm{H}-1.3}}=\alpha+\beta \mathrm{D}+\delta_{2} \mathrm{Z}_{2}+\delta_{3} \mathrm{Z}_{3}+\varepsilon=\alpha+\beta \mathrm{D}+\sum_{\mathrm{j}=2}^{3} \delta_{\mathrm{j}} \mathrm{Z}_{\mathrm{j}}+\varepsilon$ age (Bates et al. 2016) of $\mathrm{R}$ software ( $\mathrm{R}$ Core Team 2016). The lmer function was run using the default algorithm BOBYQA from the minqa package (Bates et al. 2015) as optimization algorithm.

\section{Dummy variables modelling approach}

As mentioned previously, three levels of site effects were defined and coded as 1, 2, and 3 for Mandlakaze \& Chibuto, Mabote \& Funhalouro, and Chic-

$$
\hat{H}=1.3+\frac{D^{2}}{\left(\alpha+\beta D+\sum_{j=2}^{3} \delta_{j} Z_{j}\right)^{2}}
$$

where $\delta_{j}$ - dummy parameter for site $j$ (e.g. $\delta_{2}$ dummy parameter for site 2).

Accordingly, the log-transformed Schumacher \& Hall (1933) dummy variables volume model is as follow in Eq. 11: ualacuala \& Mabalane

districts, respectively. Site 1 (Mandlakaze \& Chibuto districts) was defined as a reference or baseline site. Therefore, only two dummy variables (for Mabote \& Funhalouro and Chicualacuala \& Mabalane) were defined as follows, since $Z_{1}$ is automatically included in the intercept:

$Z_{2}=\left\{\begin{array}{l}1, \text { if the tree belongs to site } 2 \\ 0, \text { otherwise }\end{array}\right.$

$Z_{3}=\left\{\begin{array}{l}1, \text { if the tree belongs to site } 3 \\ 0, \text { otherwise }\end{array}\right.$

where $Z_{\mathrm{j}}$ - dummy variable for site $j$ (e.g. $Z_{2}$ dummy variable for site 2).

In this study, only the intercept dummy variables were considered as previously performed by Wang et al. (2007), Zeng et al. (2011), and Fu et al. (2012). Slope dummy variables were not considered. It was assumed that the dummy variables did not interact with the quantitative variables of the model (e.g. DBH). There- where $\mathrm{a}=\ln \alpha ; \varepsilon^{\prime}=\ln \varepsilon$. Therefore, the individual stem volume based in Eqs.11 is estimated using Eq. 12.

$\hat{\mathrm{V}}=\exp \left(\mathrm{a}+\sum_{\mathrm{J}=2}^{3} \boldsymbol{\delta}_{\mathrm{j}} \mathrm{Z}_{\mathrm{j}}+\mathrm{S}_{\mathrm{r}}^{2} / 2\right) \mathrm{D}^{\beta} \mathrm{H}^{\gamma}$

Analogously, back-transformation and bias correction was applied to Stoffels (1953) dummy variables volume model, resulting in Eq. 13.

$\hat{V}=\exp \left(a+\sum_{J=2}^{3} \delta_{j} Z_{j}+S_{r}^{2} / 2\right) D^{\beta}$

Dummy variables models were fitted using the $\mathrm{lm}$ function of $\mathrm{R}$ software (R Core Team, 2016). The $\operatorname{lm}$ function was run using $Q R$ algorithm.

Note that the linearization of the Näslund (1937) function which resulted in Eqs. 2 and 9 induces bias in the final volume estimate. However, this bias is considered acceptable as the linearized functions are aligned with the existing publications (e.g. Siipilehto 2000, 
Husch et al. 2003, van Laar \& Akça 2007, Schmidt et al. 2010, Kershaw Jr. et al. 2017).

\section{Evaluation and comparison}

The models were evaluated based on the following goodness-of-fit statistics: adjusted coefficient of determination (Adj. $\mathrm{R}^{2}$ ), Akaike information criterion (AIC - Akaike 1973), mean residual (MR), standard deviation of residuals $\left(\mathrm{S}_{\mathrm{r}}\right)$, and Furnival's index of fit (FI; Furnival 1961). The mean residual and the standard deviation of residuals were expressed as relative values, hereafter referred to as percent mean residual (MR [\%]) and coefficient of variation of residuals $\left(\mathrm{CV}_{\mathrm{r}}[\%]\right)$, respectively, which are more revealing.

MR measures the bias of the model, describing the directional magnitude, the size of expected under or overestimates. The ideal MR value is zero. $\mathrm{CV}_{\mathrm{r}}$ measures the dispersion between the observed and the estimated values of the model; it indicates the error that the model is subject to when is used for predicting the dependent variable. The ideal $\mathrm{CV}_{\mathrm{r}}$ value is zero. AIC gives a relative estimate of the information lost when a model is used for predicting the dependent variable. FI expresses both the size of the residuals and possible deviations from normality and homoscedasticity; i.e. FI value is increased by larger residuals, and deviation from normality and homoscedasticity.

Models resulting in largest $\mathrm{Adj}$. $\mathrm{R}^{2}$, least and not significant MR, smallest AIC, CVr and FI were selected as the best. The selected models were then validated by comparing observed and predicted values from an independent sample using aggregate difference in percentage (AD) (de Gier 1992, Husch et al. 2003) which was tested with the Wilcoxon signed rank test.

For all mixed-effects models, all regression parameters were first considered as mixed. Then, the random parameters were tested for significance using the likelihood ratio test and eliminated if not significant.

Additionally, predicted mean values from 304 mixed-effects and dummy variables models were compared to each other and to the observed mean values using column charts. The testing data were used for that purpose. All statistical analyses were performed at $\alpha=0.05$.

Mixed-effects and dummy variables $\mathrm{H}-\mathrm{D}$ and stem volume models were also compared with regard to following sources of errors in model prediction: (1) error due to model misspecification, (2) error due to uncertainty in the model parameter estimates, and (3) error due to residual variability around model prediction.

Error due to model misspecification (also known as error due to model selection or statistical model error) arises from the fact that changing the model will generally change the estimates (Cunia 1986b). When the model used fits reasonably well the sample data, the statistical model error is generally small $(\mathrm{Cu}-$ nia 1986b, McRoberts \& Westfall 2015). This error is negligible when the predictors explain a large portion of the variation of the dependent variable (Magalhães 2015a), therefore this source of error can be judged by the coefficient of determination $\left(\mathrm{R}^{2}\right)$. McRoberts \& Westfall (2015) stated that this source of error is typically not a problem when $\mathrm{R}^{2}>85 \%$.

The error due to uncertainty in the model parameter estimates is expressed by the parameter variance-covariance matrix (Magalhães 2015a). Here, this error is expressed by the standard errors of the regression parameters, as they are the square roots of the respective variances obtained from the variance-covariance matrix.

The error due to residual variability around model prediction expresses the dispersion between the observed and the estimated values by the model; therefore, it is here expressed as the coefficient of variation of the residuals $(\mathrm{CVr})$ as it is a relative measure of residual variance. The error due to residual variability around model prediction is also measured by Furnival's index of fit (FI) as it increases with increasing residuals and heteroskedasticity. 


\section{Results}

Näslund (1937) function was the best-fitting H-D model form. Schumacher and Hall (1933) function was the best-fitting volume model. However, as tree height is difficult to measure, especially in natural forests, 1-variable model form using DBH exclusively as a predictor (Stoffels 1953) was also considered. Stoffels (1953) model form performed satisfactorily.

Overall, mixed-effects models described similarly the data as the dummy variables models. All random-effects parameters of all mixed-effects models were found to be significant $(\mathrm{P}<0.0001)$; so for the dummy variables parameters (Tables 4 and 6).

Although the fixed-effects parameters of mixed-effects and dummy variables models were significant, it can be seen from Tables 4-6 that the SE of the fixed-effects parameters of mixed-effects were consistently larger than those of the dummy variables parameters. This denotes that the error due to uncertainty in the model parameter estimates was larger for mixed-effects models, as expected.

The error due to model misspecification was relatively larger for dummy variables $\mathrm{H}-\mathrm{D}$ functions (Adj. $\mathrm{R}^{2}=69.98 \%$ ) than for mixed-effects ones (Conditional $\mathrm{R}^{2}=73.76 \%$ ), however similar for volume models. The mean

Table 4 Regression parameters and goodness-of-fit statistics for Näslund (1937) H-D mixed-effects and dummy variables models

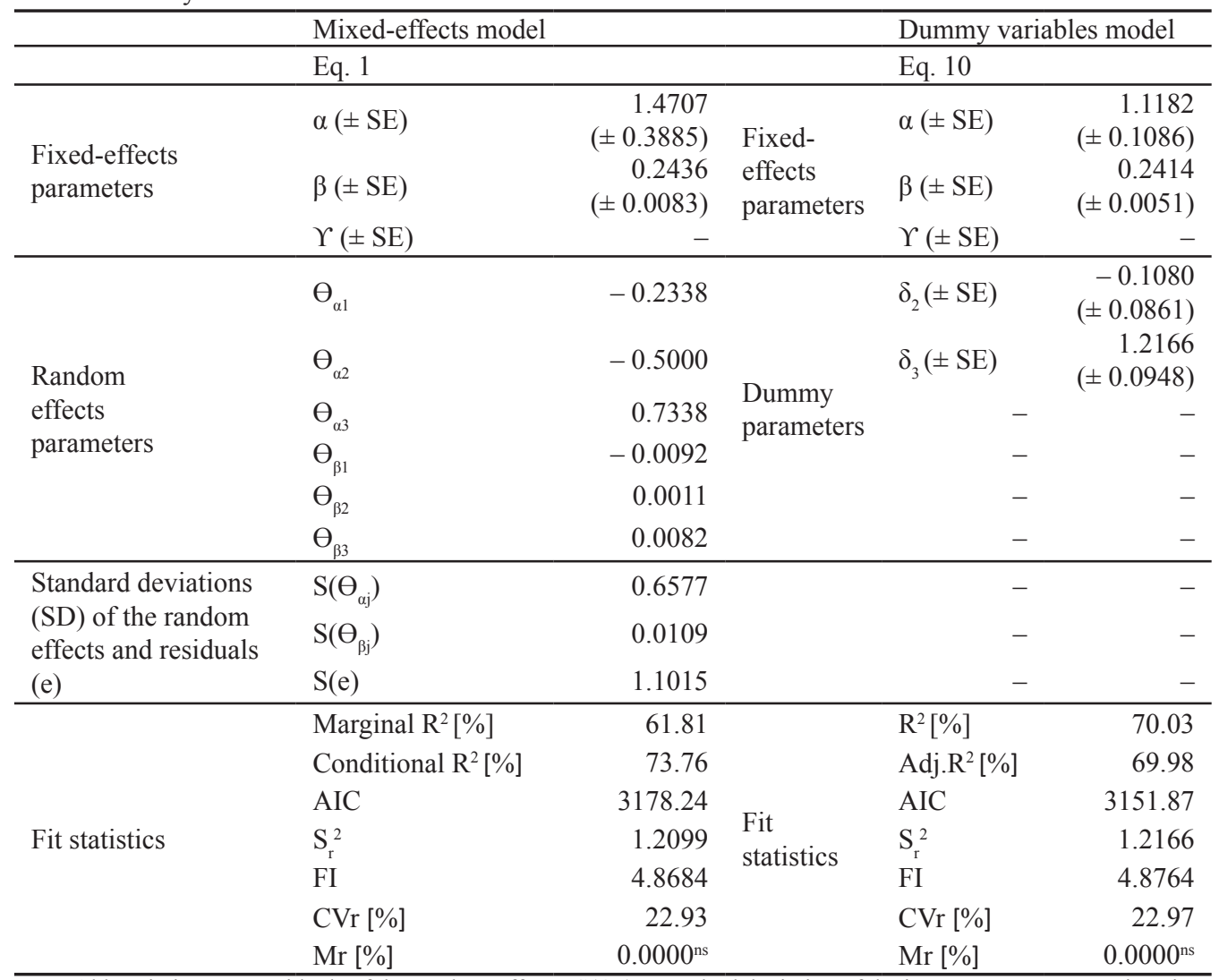

Note. Abbreviations: e - residuals of the random-effects; $\mathrm{S}\left(\Theta_{\alpha \mathrm{j}}\right)$ - standard deviation of the intercepts across growing sites; $\mathrm{S}\left(\Theta_{\beta \mathrm{j}}\right)$ - standard deviation of the slopes across growing sites; $\mathrm{S}(\mathrm{e})$ - standard deviation of the residuals of the random-effects. 
residuals (MR) were found not to be statistically significant for any modelling approach. FI and CVr were similar for both modelling approaches, suggesting similarities in terms of error due to residual variability around model prediction.

Comparing the marginal and conditional $\mathrm{R}^{2}$, it is observed that the portion of variance explained by random effects (conditional $\mathrm{R}^{2}-$ marginal $\mathrm{R}^{2}$ ) was $20 \%$ for $\mathrm{H}-\mathrm{D}$ models, and $0.34 \%$ and $2.87 \%$ for Schumacher \& Hall (1933) and Stoffels (1953) volume models, respectively.

The separated models for each growing site obtained based on the full mixed-effects and full dummy variables models (Table 7) were validated for the respective growing sites (Table 8). Overall, the aggregate differences were smaller than one percent for all models and growing sites (indicating good predictive ability), except for 1-variable volume model (either as mixed-effects or as dummy variables models) in site 3 . Wilcoxon signed rank test revealed that the predicted values did not differ from the observed ones $(\mathrm{P}>0.05)$.

The predicted heights from mixed-effects and dummy variables models are aligned to the observed ones (Figure 2A). It is also noted that for the same $\mathrm{DBH}$, sites 1 and 2 are associated with large tree heights and site 3 is associated with small tree heights.

For the same DBH (Figure 2B), predicted mean tree volumes from mixed-effects and dummy variables Stoffels (1953) volume models were in line with each other for site 1 , however, were $11 \%$ smaller than the observed

Table 5 Regression parameters and goodness-of-fit statistics for mixed-effects stem volume models

\begin{tabular}{|c|c|c|c|}
\hline & & Eq. 5 & Eq. 6 \\
\hline \multirow{3}{*}{$\begin{array}{l}\text { Fixed-effects } \\
\text { parameters }\end{array}$} & $\mathrm{a}( \pm \mathrm{SE})$ & $-10.1077( \pm 0.0532)$ & $-9.1431( \pm 0.2868)$ \\
\hline & $\beta( \pm \mathrm{SE})$ & $1.9610( \pm 0.0202)$ & $2.5086( \pm 0.0685)$ \\
\hline & $\Upsilon( \pm \mathrm{SE})$ & $1.0619( \pm 0.0303)$ & - \\
\hline \multirow{9}{*}{$\begin{array}{l}\text { Random-effects } \\
\text { parameters }\end{array}$} & $\Theta_{\mathrm{al}}$ & -0.0964 & -0.0050 \\
\hline & $\Theta_{\mathrm{a} 2}$ & 0.0748 & 0.4911 \\
\hline & $\Theta_{\mathrm{a} 3}$ & 0.0215 & -0.4861 \\
\hline & $\Theta_{\beta 1}$ & 0.0260 & 0.0012 \\
\hline & $\Theta_{\beta 2}$ & 0.0110 & -0.1146 \\
\hline & $\Theta_{\beta 3}$ & -0.0371 & 0.1134 \\
\hline & $\Theta_{\Upsilon 1}$ & -0.0236 & - \\
\hline & $\Theta_{Y_{2}}$ & -0.0322 & - \\
\hline & $\theta_{r_{3}}$ & 0.0558 & - \\
\hline \multirow{4}{*}{$\begin{array}{l}\text { Standard deviations } \\
\text { (SD) of the random- } \\
\text { effects and residuals (e) }\end{array}$} & $\mathrm{SD}\left(\Theta_{\mathrm{aj}}\right)$ & 0.0889 & 0.4901 \\
\hline & $\operatorname{SD}\left(\Theta_{\beta j}\right)$ & 0.0337 & 0.1143 \\
\hline & $\operatorname{SD}\left(\Theta_{\Upsilon \mathrm{j}}\right)$ & 0.0504 & - \\
\hline & $\mathrm{SD}(\mathrm{e})$ & 0.0606 & 0.2870 \\
\hline \multirow{7}{*}{ Fit statistics } & Marginal $\mathrm{R}^{2}[\%]$ & 99.44 & 92.41 \\
\hline & Conditional $\mathrm{R}^{2}[\%]$ & 99.78 & 95.06 \\
\hline & AIC & -2811.01 & 388.20 \\
\hline & $\mathrm{S}_{\mathrm{r}}^{2}$ & 0.0037 & 0.0822 \\
\hline & FI & 0.0036 & 0.0173 \\
\hline & $\mathrm{CVr}[\%]$ & 10.75 & 33.29 \\
\hline & $\operatorname{Mr}[\%]$ & $0.0363^{\mathrm{ns}}$ & $-0.0220^{\mathrm{ns}}$ \\
\hline
\end{tabular}


Table 6 Regression parameters and goodness-of-fit statistics for dummy variables stem volume models

\begin{tabular}{llrr}
\hline & & \multicolumn{1}{c}{ Eq. 12} & \multicolumn{1}{c}{ Eq. 13 } \\
\hline \multirow{2}{*}{ Fixed-effects } & $\mathrm{a}( \pm \mathrm{SE})$ & $-10.2265( \pm 0.0137)$ & $-9.0650( \pm 0.0527)$ \\
parameters & $\beta( \pm \mathrm{SE})$ & $1.9524( \pm 0.0053)$ & $2.4803( \pm 0.0186)$ \\
& $\Upsilon( \pm \mathrm{SE})$ & $1.0869( \pm 0.0074)$ & \multicolumn{1}{c}{-} \\
\hline Dummy & $\delta_{2}( \pm \mathrm{SE})$ & $0.1078( \pm 0.0048)$ & $0.1979( \pm 0.0225)$ \\
parameters & $\delta_{3}( \pm \mathrm{SE})$ & $0.1307( \pm 0.0058)$ & $-0.2253( \pm 0.0246)$ \\
\hline \multirow{5}{*}{ Fit statistics } & $\mathrm{R}^{2}[\%]$ & 99.77 & 94.90 \\
& $\mathrm{Adj} . \mathrm{R}^{2}[\%]$ & 99.77 & 94.90 \\
& $\mathrm{AIC}$ & -2830.05 & 382.21 \\
& $\mathrm{~S}_{\mathrm{r}}^{2}$ & 0.0038 & 0.0842 \\
& $\mathrm{FI}$ & 0.0037 & 0.0175 \\
& $\mathrm{CVr}[\%]$ & 10.93 & 33.46 \\
& $\mathrm{Mr}[\%]$ & $0.1558^{\mathrm{ns}}$ & $-0.9161^{\mathrm{ns}}$ \\
\hline
\end{tabular}

Note. Abbreviation: ns - not statistically significant.

Table 7 Separated mixed-effects and dummy variables models for each growing site

\begin{tabular}{|c|c|c|c|c|}
\hline $\begin{array}{l}\text { Charc- } \\
\text { teristics }\end{array}$ & Model & Growing site 1 & Growing site 2 & Growing site 3 \\
\hline \multirow[t]{3}{*}{$\begin{array}{l}\text { Mixed- } \\
\text { effects } \\
\text { models }\end{array}$} & H-D model & $\begin{array}{l}\mathrm{H}=1.3+\left(\mathrm{D}^{2} /(1.2369\right. \\
\left.+0.2344 \times \mathrm{D})^{2}\right)\end{array}$ & $\begin{array}{l}\mathrm{H}=1.3+\left(\mathrm{D}^{2} /(0.9707\right. \\
\left.+0.2447 \times \mathrm{D})^{2}\right)\end{array}$ & $\begin{array}{l}\mathrm{H}=1.3+\left(\mathrm{D}^{2} /(2.2045\right. \\
\left.+0.2518 \times \mathrm{D})^{2}\right)\end{array}$ \\
\hline & \multirow{2}{*}{$\begin{array}{l}\text { 2-variable } \\
\text { volume model } \\
1 \text {-variable } \\
\text { volume model }\end{array}$} & $\begin{array}{l}\mathrm{V}=0.000037 \times \mathrm{D}^{1.9870} \\
\times \mathrm{H}^{1.0383}\end{array}$ & $\begin{array}{l}\mathrm{V}=0.000044 \times \mathrm{D}^{1.9720} \\
\times \mathrm{H}^{1.0297}\end{array}$ & $\begin{array}{l}\mathrm{V}=0.000042 \times \mathrm{D}^{1.9239} \\
\times \mathrm{H}^{1.1177}\end{array}$ \\
\hline & & $\mathrm{V}=0.000111 \times \mathrm{D}^{2.5098}$ & $\mathrm{~V}=0.000182 \times \mathrm{D}^{2.3940}$ & $\mathrm{~V}=0.000069 \times \mathrm{D}^{2.6220}$ \\
\hline \multirow[t]{3}{*}{$\begin{array}{l}\text { Dummy } \\
\text { variables } \\
\text { models }\end{array}$} & H-D model & $\begin{array}{l}\mathrm{H}=1.3+\left(\mathrm{D}^{2} /(1.1182\right. \\
\left.+0.2414 \times \mathrm{D})^{2}\right)\end{array}$ & $\begin{array}{l}\mathrm{H}=1.3+\left(\mathrm{D}^{2} /(1.0102\right. \\
\left.+0.2414 \times \mathrm{D})^{2}\right)\end{array}$ & $\begin{array}{l}\mathrm{H}=1.3+\left(\mathrm{D}^{2} /(2.3348\right. \\
\left.+0.2414 \times \mathrm{D})^{2}\right)\end{array}$ \\
\hline & \multirow{2}{*}{$\begin{array}{l}\text { 2-variable } \\
\text { volume model } \\
1 \text {-variable } \\
\text { volume model }\end{array}$} & $\begin{array}{l}\mathrm{V}=0.000036 \times \mathrm{D}^{1.9524} \\
\times \mathrm{H}^{1.0869}\end{array}$ & $\begin{array}{l}\mathrm{V}=0.000040 \times \\
\mathrm{D}^{1.9524} \times \mathrm{H}^{1.0869}\end{array}$ & $\begin{array}{l}\mathrm{V}=0.000041 \times \\
\mathrm{D}^{1.9524} \times \mathrm{H}^{1.0869}\end{array}$ \\
\hline & & $\mathrm{V}=0.000120 \times \mathrm{D}^{2.4803}$ & $\mathrm{~V}=0.000147 \times \mathrm{D}^{2.4803}$ & $\mathrm{~V}=0.000096 \times \mathrm{D}^{2.4803}$ \\
\hline
\end{tabular}

Note that, for example, for 2-variables volume model for growing site 1 derived from the full mixed-effects model, the regression parameter $0.000037=\exp \left(\alpha+\Theta_{\alpha 1}+\operatorname{Sr}_{2} / 2\right)=\exp (-10.1077-0.0964+0.0037)$ and $1.9870=\beta+\Theta_{\beta 1}=$ $1.9610+0.0260$, and so on (see Table 5). On the other hand, for 2-variables volume model for growing site 1 derived from the dummy variables model, the regression parameter $0.000036=\exp \left(\alpha+\mathrm{Sr}_{2} / 2\right)=\exp (-10.2265+0.0038 / 2)$; note that since site 1 was defined as the reference site, $\delta_{1}$ (dummy parameter for site 1 ) does not exist (i.e. there is only $\left.\delta_{2}, \delta_{3}\right)$; however, for site 2 the parameter $0.000040=\exp \left(\alpha+\delta 2 \times \mathrm{Z} 2+\delta 3 \times \mathrm{Z} 3+\mathrm{Sr}_{2} / 2\right)=\exp (-10.2265+0.1078 \times 1+$ $0.1307 \times 0+0.0038 / 2$ ), and so on for site 3 (see Table 6 and Eq. 12); recall that $Z_{2}=1$ if the tree belongs to site 2 and $Z_{2}$ $=0$, otherwise (see Eqs. 7 and 8).

mean volume, resulting in underestimation. Both modelling approaches overestimate the mean volume in sites 2 and 3. However, in site 3 , the mixed-effects model overestimate it in larger extent compared with the dummy vari- ables model (i.e., $25 \%$ vs. $8 \%$, respectively).

For the same DBH and height, mixed-effects and dummy variables Schumacher \& Hall (1933) volume models provided biased predictions (Figure 2, C and D), underestimating the 
Table 8 Validation of the selected models

\begin{tabular}{lllllll}
\hline \multirow{2}{*}{ Model } & Site 1 & \multicolumn{3}{c}{ Site 2 } & \multicolumn{3}{c}{ Site 3 } \\
\cline { 2 - 7 } & $\mathrm{AD} \mathrm{[ \% ]}$ & $p$ & $\mathrm{AD}[\%]$ & $p$ & $\mathrm{AD}[\%]$ & $p$ \\
\hline Mixed-effects H-D model & -0.4340 & 0.1768 & -0.4370 & 0.0600 & 0.2833 & 0.9865 \\
Dummy H-D model & -0.4624 & 0.1768 & -0.3870 & 0.2685 & 0.2939 & 0.8793 \\
\hline Mixed-effects 1-variable volume model & 0.3827 & 0.6088 & 0.6716 & 0.1162 & 1.5026 & 0.2700 \\
Dummy 1-variable volume model & 0.2836 & 0.5250 & 0.7097 & 0.0670 & 1.1278 & 0.4500 \\
\hline Mixed-effects 2-variables volume model & 0.2108 & 0.6806 & 0.3134 & 0.8765 & 0.6339 & 0.9876 \\
Dummy 2-variables volume model & 0.1747 & 0.7154 & 0.3147 & 0.0579 & 0.6965 & 0.5643 \\
\hline
\end{tabular}

Note. Abbreviation: AD - aggregate difference; $p$ - $p$-value for Wilcoxon signed rank test.

mean tree volume for sites 1 and 2 and overestimating it for site 3 . However, it should be noted that for the same $\mathrm{DBH}$, trees from site 3 are much shorter than trees from sites 1 and 2 (Table 2, Figure 2A). Therefore, it is unrealistic to keep $\mathrm{DBH}$ and height constant, thus the conclusion above is misleading. By allowing the height to vary between sites (e.g. by using predicted height from the selected $\mathrm{H}-\mathrm{D}$ function) that ambiguity is solved. By including the site effect on height, it is noted from Figure 2 (C and D) that the predicted mean tree volume from mixed-effects and dummy variables Schumacher \& Hall (1933) models are in accordance with observed ones in all sites.

\section{Discussion}

The present study provides the first H-D and stem volume models for Lebombo-ironwood and the first models incorporating site-effects for Mozambique. These newly developed models represent a valuable tool for management of Lebombo-ironwood stands in Mozambique.

Many authors fitted H-D models using tree heights obtained with the trees standing (Sharma \& Parton 2007, Adame et al. 2008, Coble \& Lee 2011, Schimidt et al. 2011, de-Miguel et al. 2013, Missanjo \& Mwale 2014, Petráš et al. 2014) and therefore more prone to measuring errors. In this study, tree heights were obtained on felled trees, thus more accurate. Moreover, the top part of the Lebombo-ironwood trees remained unaffected after felling (did not break) thus, underestimations due to broken top part are unlikely.

The Näslund function (Näslund 1937) was the best H-D model. This function was tested successfully by many authors either as fixed-, mixed-effects or dummy variables model (Kangas \& Maltamo 2002, Kinnunen et al. 2007, Schimidt et al. 2011, Missanjo \& Mwale 2014, Mehtätalo et al. 2015).

Overall, negligible differences were observed between mixed-effects and dummy variables models; which was expected, since in case of large sample size the mixed-effects and dummy variables modelling approaches are not significantly different from each other (Fu et al. 2012, Zeng 2014). In this study the training sample size is considered large (n =1037), as defined by Freese $(1962,1984)$, Stauffer (1983), Stellingwerf (1994) and Husch et al. (2003) (n > 30). Zeng (2014) stated that mixed-effects models are recommended over dummy variable models when the sample size is small $(\mathrm{n}<30)$.

The lack of significant differences in performance, predictive ability and accuracy between mixed-effects and dummy variables models suggests that those two modelling approaches can be used indiscriminately. However, in general, mixed-effects models have the following advantages over dummy variables models that must be kept in mind:

(1) under the assumption that the sampled 

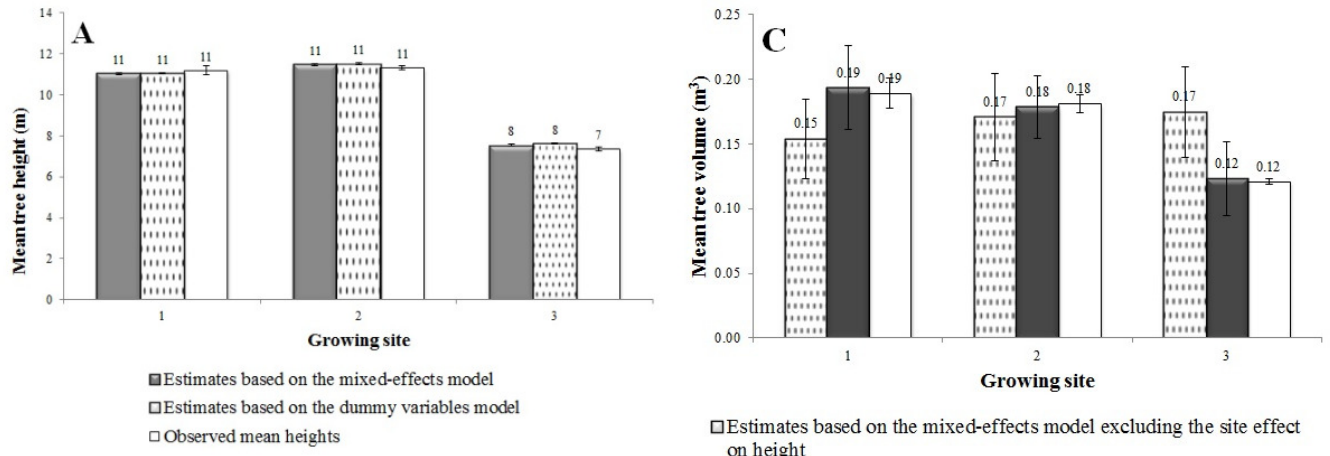

$$
\begin{aligned}
& \square \text { Estimates based on the mixed-effects model excluding the site effect } \\
& \text { on height } \\
& \text { घEstimates based on the mixed-effects model including the site effect } \\
& \text { on height } \\
& \square \text { Observed mean tree volume }
\end{aligned}
$$
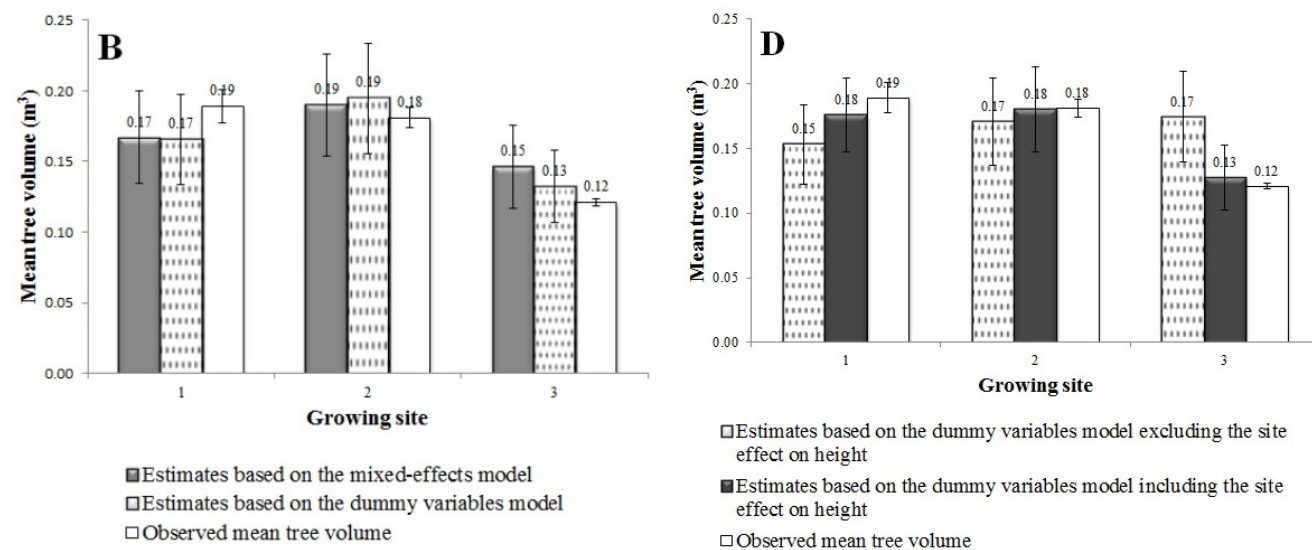

Figure 2 Effect of growing sites (either as random-effects or dummy parameters) on: (A) tree height estimates, (B) predicted mean tree volume from 1-variable stem volume model, (C) predicted mean tree volume from 2-variables volume model, and (D) on predicted mean tree volume from 2-variables volume model. Error bars indicate $95 \%$ confidence interval $(\mathrm{CI})$ computed as $\mathrm{CI}= \pm \mathrm{t} \times \mathrm{SE}$; where $t$ is the critical value of $t$ distribution at $95 \%$ of probability and $n-1$ degrees of freedom; $n$ is the sample size; and SE is the standard error.

sites are representative of all sites where Lebombo-ironwood occurs, mixed-effects models can be calibrated for new, previously not sampled sites quickly and effectively (Saunders \& Wagner 2008, Mehtätalo et al. 2015). This assumption is met, as this species occurs in a narrow climatic, altitudinal (Table 1) and soil conditions (Magalhães \& Seifert 2015a,b, Magalhães 2015a, b).

(2) mixed-effects models reduce interdependence among measurements from the same growing site by defining a covariance matrix among random parameters within and among sites (Calama \& Montero 2004).

On the other hand, dummy variables models have the advantage of directly including variables defining the between-site variability, and in practice are more easily applicable.

The fact that the portion of variance explained by random effects (conditional $\mathrm{R}^{2}-$ marginal $\mathrm{R}^{2}$ ) in mixed-effects 2 -variable volume model was only $0.34 \%$ suggested that the 
fixed-effects 2-variable model could be used as a standard volume model (as opposed to local volume). However, the tests of significance of random-effects parameters proved otherwise. The variance explained by random effects in 2-variable volume model was negligible because the height (as second variable) indirectly includes site effects, as the $\mathrm{H}-\mathrm{D}$ relationship is modified by site quality (Sharma \& Zhang 2004).

Schumacher \& Hall (1933) volume model (either as mixed-effects or as dummy variables models) fitted the data better than the Stoffels (1953) volume model (1-variable one); thus, in that sense, it is the best for predicting Lebombo-ironwood stem volume. However, the 1-variable volume model also performed satisfactorily and has the advantage of being cheap, easy to use and less susceptible to measuring errors, as it uses only DBH as a predictor. When validating the models, mixed-effects and dummy variables 1 -variable models showed a relative weakness in site 3 , as they had relatively larger $\mathrm{AD}$ values (1.50 and $1.13 \%$, respectively). De Gier (1994) argued that $\mathrm{AD}$ should not exceed $1 \% ; 2$-variables volume models (as mixed-effects and dummy variables models) however, had $\mathrm{AD}<1 \%$ for all sites.

\section{Conclusions}

The newly developed H-D and stem volume models are a valuable tool for management of Lebombo-ironwood stands in Mozambique. Mixed-effects and dummy variables models did not differ in terms of predictive ability and accuracy, thus as long as the advantages and disadvantages of each modelling approach are kept in mind they can be used for estimating tree height and stem volume.

\section{Acknowledgements}

This work was supported by Universidade 310
Eduardo Mondlane (through Fundo Aberto), Danish International Development Agency (DANIDA) and the Swedish International Development Cooperation Agency (SIDA). Thanks are extended to the field team and to the anonymous reviewers.

\section{References}

Adame P., Del Rio M., Canellas I., 2008. A mixed nonlinear height-diameter model for pyrenean oak (Quercus pyrenaica Willd.). F orest Ecology and Management 256, 88-98. DOI: 10.1016/j.foreco.2008.04.006

Akaike H., 1973. Information theory as an extension of the maximum likelihood principle. In: Petrov BN, Csaki F (ed.) Second international symposium on information theory. Budapest, Akademiai Kiado, pp 267-281.

Baltagi, B.H., 2005. Econometric analysis of panel data, 3rd ed. John Wiley \& Sons, Ltd., 302p.

Baskerville, G.L., 1972. Use of logarithmic regression in the estimation of plant biomass. Canadian Journal of Forest Research 2: 49-53. DOI: 10.1139/x72-009

Bates D., Maechler M., Bolker B., Walker S., Haubo R., Singmann H., Dai B., Grothendieck G., 2016. Lmer4: Linear mixed-effects models using 'Eigen' and S4 (R Package Version 1.1-12). Vienna: R Foundation for Statistical Computing.

Bates D., Mullen K.M., Nash J.C., Varadhan R., 2015. Minqa: Derivative-free optimization algorithms by quadratic approximation (R Package Version 1.2.4). Vienna: R Foundation for Statistical Computing.

Bunster J., 2006. Commercial timbers of Mozambique. Traforest Lda, Maputo, 62 p.

Calama R., Montero G., 2004. Interregional nonlinear height-diameter model with random coefficients for stone pine in Spain. Canadian Journal of Forest Research 34: 150-163. DOI: 10.1139/x03-199

Cardoso G.A., 1963. Madeiras de Moçambique: Androstachys johnsonii. Serviços de Agricultura e Serviços de Veterinária, Maputo, 59p.

Castedo Dorado F., Diéguez-Aranda U., Barrio Anta M., Sanchez Rodríguez M., von Gadow, K., 2006. A generalized height-diameter model including random components for radiata pine plantations in northwestern Spain. Forest Ecology and Management 229: 202-213. DOI: $10.1016 /$ j.foreco.2006.04.028

Chave J., Andalo C., Brown S. et al., 2005. Tree allometry and improved estimation of carbon stocks and balance in tropical forests. Oecologia 145: 87-99. DOI: 10.1007/s00442-005-0100-x

Coble D.W., Lee Y.J., 2011. A mixed-effects height model for individual loblolly and slash pine trees in east Texas. Southern Journal of Applied Forestry 35(1): 12-17.

Cunia T., 1986a. Use of dummy variables techniques in the estimation of biomass regressions. In: Wharton E.H., Cunia T. (ed.), Estimating tree biomass regres- 
sions and their error. NE-GTR-117. PA, USDA, Forest Service, Northeastern Forest Experiment Station, Broomall, pp 37-48.

Cunia T., 1986b. Error of forest inventory estimates: its main components. In: Wharton E.H., Cunia T. (ed.), Estimating tree biomass regressions and their error. NE-GTR-117. PA, USDA, Forest Service, Northeastern Forest Experiment Station, Broomall, pp. 1-13.

de Gier I.A., 1992. Forest mensuration (fundamentals). International Institute for Aerospace Survey and Earth Sciences (ITC), The Netherlands, $67 \mathrm{p}$.

De-Miguel S., Guzmán G., Pukkala T., 2013. A comparison of fixed- and mixed-effects modeling in tree growth and yield prediction of an indigenous neotropical species (Centrolobium tomentosum) in a plantation system. Forest Ecology and Management 291: 249-258. DOI: 10.1016/j.foreco.2012.11.026

DINAGECA, 1997. Mapa digital de uso e cobertura de terra [Digital map of land use and land cover]. Cenacarta, Maputo.

FAO, 2003. FAO map of world soil resources, Rome.

Fekedulengn D., Siurtain M.P.M., Colbert J.J., 1999. Parameter estimation of nonlinear growth models in forestry. Silva Fennica 33: 327-336.

Freese F., 1962. Elementary forest sampling. US Department of Agriculture, Washington DC, $91 \mathrm{p}$.

Freese F., 1984. Statistics for land managers. Paeony Press, Edinburgh, 178 p.

Fu L.Y., Zeng W.S., Tang S.Z. et al. 2012. Using linear mixed model and dummy variable model approaches to construct compatible single-tree biomass equations at different scales - a case study for Masson pine in southern China. Journal of Forest Science 58(3): 101-115.

Furnival G.M. 1961. An index for comparing equations used in constructing volume tables. Forest Science 7: 337-341.

Garavaglia S., Sharma A., 2000. A smart guide to dummy variables: four applications and a macro. Murray Hill, New Jersey, 10 p.

Gelman A., 2005. Analysis of variance-why it is more important than ever. Annals of Statistics 33(1): 1-53. DOI: $10.1214 / 009053604000001048$

Huang S., Price D., Titus S.J., 2000. Development of ecoregion-based height-diameter models for white spruce in boreal forests. Forest Ecology and Management 129: 125-141. DOI: 10.1016/S0378-1127(99)00151-6

Husch B., Beers T.W., Kershaw J.A. Jr., 2003. Forest mensuration $\left(4^{\text {th }}\right.$ ed.). John Willey and Sons, New Jersey, $433 \mathrm{p}$.

Kangas A., Maltamo M., 2002. Anticipating the variance of predicted stand volume and timber assortments with respect to stand characteristics and field measurements. Silva Fennica 36(4): 799-811. DOI: 10.14214/sf.522

Kershaw Jr. J.A., Ducey M.J., Beers T.W., Husch B., 2017. Forest mensuration ( $5^{\text {th }}$ edition). John Willey and Sons, Oxford, $613 \mathrm{p}$.

Kinnunen J., Maltamo M., Päivinen R., 2007. Standing volume estimates of forests in Russia: how accurate is the published data? Forestry 80(1): 53-64. DOI: 10.1093/forestry/cpl042
Li L.X., Hao Y.H., Zhang Y., 2006. The application of dummy variable in statistical analysis. The Journal of Mathematical Medicine 19: 51-52. (in Chinese)

Loetsch F., Zohrer F., Haller K.E., 1973. Forest inventory. Volume II. BLV Verlagsgesellschaft, Munchen, 469 p.

MAE. 2005a. Perfil do distrito de Funhalouro, província de Inhambane [Profile of Funhalouro district, Inhambane province]. Ministério da Administração Estatal, Maputo, $44 \mathrm{p}$.

MAE. 2005b. Perfil do distrito de Mabote, província de Inhambane [Profile of Mabote district, Inhambane province]. Ministério da Administração Estatal, Maputo, 43 p.

MAE. 2005c. Perfil do distrito de Chibuto, província de Gaza [Profile of Chibuto district, Gaza province]. Ministério da Administração Estatal, Maputo, 44 p.

MAE. 2005d. Perfil do distrito de Mandlakazi, província de Gaza [Profile of Mandlakazi district, Gaza province]. Ministério da Administração Estatal, Maputo, 45 p.

MAE. 2005e. Perfil do distrito de Mabalane [Profile of Mabalane district, Gaza province], província de Gaza. Ministério da Administração Estatal, Maputo, 45 p.

MAE. 2005f. Perfil do distrito de Chicualacuala, província de Gaza [Profile of Chicualacuala district, Inhambane province]. Ministério da Administração Estatal, Maputo, $42 \mathrm{p}$.

Magalhães T.M., 2015a. Live above- and belowground biomass of a Mozambican evergreen forest: a comparison of estimates based on regression equations and biomass expansion factors. Forest Ecosystems 2: 28. DOI: 10.1186/s40663-015-0053-4

Magalhães T.M., 2015b. Allometric equation for estimating belowground biomass of Androstachys johnsonii Prain. Carbon Balance and Management 10: 16. DOI: 10.1186/s13021-015-0027-4

Magalhães T.M., Seifert T., 2015a. Tree component biomass expansion factors and root-to-shoot ratio of Lebombo ironwood: measurement uncertainty. Carbon Balance and Management 10: 9. DOI: 10.1186/s13021015-0019-4

Magalhães T.M., Seifert T., 2015b. Biomass modelling of Androstachys johnsonii Prain - a comparison of three methods to enforce additivity. International Journal of Forestry Research 2015: 1-17. DOI: $10.1155 / 2015 / 878402$

McRoberts R.E., Westfall J.A., 2015. Propagating uncertainty through individual tree volume model predictions to large-area volume estimates. Annals of Forest Science 73: 625-633. DOI: 10.1007/s13595-015-0473-x

Mehtätalo L., de-Miguel S., Gregoire T.G., 2015. Modeling height-diameter curves for prediction. Canadian Journal of Forest Research 45: 826-837. DOI: 10.1139/ cjfr-2015-0054

Menten L., Michaelis M.I., 1913. Die kinetik der invertinwirkung [The kinetics of invertin action]. Biochemische Zeitschrift 49: 333-369.

Missanjo E., Mwale G., 2014. A mixed-effects height-diameter model for Pinus kesiya in Malawi. Journal of Biodiversity Management \& Forestry 3: 2.

Molotja G.M.; Ligavha-Mbelengwa M.H., Bhat R.B., 
2011. Antifungal activity of root, bark, leaf and soil extracts of Androstachys johnsonii Prain. African Journal of Biotechnology 10(30): 5725-5727.

Mugasha W.A., Mwakalukwa E.E., Luoga E. et al. 2016. Allometric models for estimating tree volume and aboveground biomass in lowland forests of Tanzania. International Journal of Forestry Research 2016: 1-13. DOI: 10.1155/2016/8076271

Näslund M., 1937. Skogsförsöksanstaltens gallringsförsök i tallskog [Forest research intitute's thinning experiments in Scots pine forests]. Meddelanden frstatens skogsförsöksanstalt Häfte 29 (In Swedish).

Parresol B.R., 1999. Assessing tree and stand biomass: a review with examples and critical comparisons. Forest Science 45(4): 573-593.

Petráš R., Bašela M., Mecko J., Ozslányi J., Popa I., 2014. Height-diameter models for mixed-species forests consisting of spruce, fir, and beech. Folia Forestalia Polonica 56(2): 93-104. DOI: 10.2478/ffp-2014-0009

Philip S.M., 1994. Measuring trees and forests ( $2^{\text {nd }}$ ed.). CAB International, Wallingford, $310 \mathrm{p}$.

$\mathrm{R}$ Core Team, 2016. A language and environment for statistical computing. Vienna: R Foundation for Statistical Computing.

Saunders M.R., Wagner R.G., 2008. Height-diameter models with random coefficients and site variables for tree species of Central Maine. Annals of Forest Science 65: 203-212. DOI: 10.1051/forest:2007086

Schimidt M., Kiviste A., von Gadow K., 2011. A spatially explicit height-diameter model for Scots pine in Estonia. European Journal of Forest Research 130: 303-315. DOI: $10.1007 / \mathrm{s} 10342-010-0434-8$

Schumacher F.X., Hall F., 1933 Logarithmic expression of timber-tree volume. Journal of Agriculture Research 47: 719-734.

Sharma K., Parton J., 2007. Height-diameter equations for boreal tree species in Ontario using a mixed-effects modeling approach. Forest Ecology and Management 249: 187-198. DOI: 10.1016/j.foreco.2007.05.006

Sharma M., Zhang S.Y., 2004. Height-diameter models using stand characteristics for Pinus banksiana and $\mathrm{Pi}$ - cea mariana. Scandinavian Journal of Forest Research 19: 442-451. DOI: 10.1080/02827580410030163

Siipilehto, J. 2000. A comparison of two parameter prediction methods for stand structure in Finland. Silva Fennica 34(4): 331-349. DOI: 10.14214/sf.617

Spurr H.,1952. Forest inventory. Ronald Press, New York. Stauffer H.B., 1983. Some sample size tables for forest sampling. Ministry of Forests, British Columbia, $50 \mathrm{p}$.

Stellingwerf, D.A., 1994. Forest inventory and remote sensing. International Training Centre for Aerial Survey (ITC), Enschede, 132p.

Stoffels A., 1953. De inhoudsbepaling van grovedennen opstanden met behulp van standardkrommen. Nederlands Bosbouw Tijdschrift: 29-42.

Strand L., 1959. The accuracy of some methods for estimating volume and increment on sample plots. Meddelelser Norske Skogforscksvesen 15(4): 284-392.

Tang S.Z., Lang K.J., Li H.K., 2008. Statistics and computation of biomathematical models. Beijing, Science Press: 115-261 (In Chinese).

van Laar A., Akça A., 2007. Forest mensuration. Springer, Dordrecht, 383p. DOI: 10.1007/978-1-4020-5991-9

Wang M., Borders B.E., Zhao D., 2007. Parameter estimation of base-age invariant site index models: which data structure to use? Forest Science 53 (5): 541-551.

Wang M., Borders B.E., Zhao D., 2008. An empirical comparison of two subject-specific approaches to dominant heights modeling: the dummy variable method and the mixed model method. Forest Ecology and Management 255: 2659-2669. DOI: 10.1016/j.foreco.2008.01.030

Zeng W.S, Zhang H.R, Tang, S.Z, 2001. Using the dummy variable model approach to construct compatible single-tree biomass equations at different scales - a case study for Masson pine (Pinus massoniana) in southern China. Canadian Journal of Forest Research 41: 15471554. DOI: $10.1139 / \mathrm{x} 11-068$

Zeng W.S., 2014. Using nonlinear mixed model and dummy variable model approaches to develop origin-based individual tree biomass equations. Trees 29(1): 275283. DOI: $10.1007 / \mathrm{s} 00468-014-1112-0$ 